This is a postprint (peer-reviewed and accepted version) of the chapter ${ }^{1}$ published in the book Transforming Digital Worlds (Springer). DOI: https://doi.org/10.1007/978-3-319-78105-1_73

\title{
Is There a Solution to the Orphan Works Problem? Exploring the International Models
}

\author{
Brenda Siso-Calvo ${ }^{1[0000-0002-1376-4072]}$, Rosario Arquero-Avilés ${ }^{1[0000-0002-3097-8734]}$, Gonzalo \\ Marco-Cuenca $^{2[0000-0002-7149-6192]}$ and Silvia Cobo-Serrano ${ }^{3}$ \\ ${ }^{1}$ Complutense University, Madrid, Spain \\ msiso@ucm.es, carquero@ucm.es \\ ${ }^{2}$ University of Zaragoza, Zaragoza, Spain \\ gmarco@unizar.es \\ ${ }^{3} \mathrm{PhD}$ in Library and Information Science, Madrid, Spain \\ s.cobo@ucm.es
}

\begin{abstract}
Aspects related to copyright and orphan works become a real obstacle for cultural institutions wishing to undertake major projects for the digitisation and on-line availability of their collections. Although some countries have already established models to try to solve the problem of orphan works, others are still discussing possible options. The paper explores the current situation of the schemes in place internationally to deal with the problems associated with orphan works and how these are being applied by cultural institutions regarding the digital dissemination of their collections. The methodology consisted in a systematic review of the research results as an exploratory analytical technique for the collection of relevant information. Results highlighted that global situation is uncertain and none of the formulas studied enables full and effective digitisation and digital dissemination of the world's cultural heritage. Further advances are necessary for the creation of diligent search procedures.
\end{abstract}

Keywords: Orphan works, Digitisation, Online Dissemination, Libraries, Cultural heritage, Documentary Heritage, Copyright, Diligent Search.

\footnotetext{
${ }^{1}$ Siso-Calvo B., Arquero-Avilés R., Marco-Cuenca G., Cobo-Serrano S. (2018) Is There a Solution to the Orphan Works Problem? Exploring the International Models. In: Chowdhury G., McLeod J., Gillet V., Willett P. (eds) Transforming Digital Worlds. iConference 2018. Lecture Notes in Computer Science, vol 10766, pp. 638-644. Springer, Cham
} 


\section{Introduction}

Digitisation of documentary heritage for its online availability is already a reality. Cultural institutions are considering the digitisation of their collections for their digital conservation and, mainly, to ensure that the public can access worldwide cultural heritage [1]. Major digitisation projects are under way or being implemented across the globe: World Digital Library, Digital Public Library of America or Europeana.

Although a digital setting offers many possibilities for making cultural material more accessible, institutions must bear in mind several key points regarding copyright. The main challenge consists in understanding the feasibility of copyright, and this is the moment at which orphan works become an obstacle for the dissemination of cultural heritage. "Works are called orphan when rights holders cannot be identified or, if they are identified, they cannot be located in order to ask the necessary permissions" [2, p.63].

Although some countries have already established models to try to solve the problem of orphan works, others are still discussing possible options. "In most solutions there is a need to define a criterion on what constitutes a diligent search ${ }^{2}$ that needs to be performed prior to the use of a work" [2, p.63].

\section{Goals and Methodology}

The paper focuses on explore the current situation of the schemes in place internationally to deal with the problems associated with orphan works and how these are being applied by cultural institutions relating to the digitisation and digital dissemination of their collections. Our specific goals are to describe the current models in order then to characterize the degree of development of guidelines and standards for carrying out diligent searches prior to declaring a work as orphaned or applying for a copyright licence. Another element of significance for analysis, given the focus on Library and Information Science area, is the existence of lists of information sources and identification of databases or registers aimed at monitoring diligent search efforts at both national and entity level. Lastly, to identify some of the initiatives undertaken by different cultural institutions to solve copyright aspects.

We undertook a systematic review of the research results published by expert authors and research groups working in the field under study, as well as official reference documents and regulations from domestic and international authorities. Initial phase included the review of scientific literature and a subsequent analysis of the data and the summary of this information.

\section{Results and Discussion}

\subsection{Statutory Exception-Based Model}

Also known as the European model, was adopted by the European Union through the approval of European Directive 2012/28/EU on the authorized uses of orphan works [4], which established the legal framework to facilitate the digitisation and dissemination of certain copyrighted works by cultural institutions.

Article 3 of European Directive stipulates that beneficiaries shall ensure a diligent search is made in good faith for each protected work, consulting appropriate sources for the purpose depending on the category of work. The results obtained by multiple research

\footnotetext{
${ }^{2}$ Diligent search refers to a search procedure whose aim is to identify and locate the copyright holder(s) of a possible orphan work. This procedure is compulsory and must be carried out before an item is declared an orphan work [3].
} 
teams [5-7] have confirmed through relevant evidence that only the United Kingdom has set up detailed procedures or guidelines to deal with diligent searches about orphan works.

The Directive also promotes the adoption by member states of the measures necessary to ensure that information about orphan works is recorded on a central on-line database accessible to the public. To this end, the European Union Intellectual Property Office (EUIPO) handles the European Union Orphan Works Database, on which each competent national authority can register the information necessary to identify a work as an orphan in a country, so that it receives the same recognition throughout the European Union [3].

The total number of orphan works declared and registered on the European Union Orphan Works Database comes to 5,142 records [5], implying an increase of 3,712 records with respect to the data reflected in the EUIPO Report for 2015 [8, p.50].

\subsection{Fair Use}

Fair use is a copyright principle based on the belief that the public is entitled to freely use portions of copyrighted materials for purposes such as criticism, comment, news reporting, teaching, scholarship, or research [9]. In the United States, this principle is governed by Title 17 of the Copyright Law and is being used as an effective solution for the problem posed by orphan works ${ }^{3}$.

Cultural institutions wishing to engage in digitisation projects must rely on fair use to make their documentary heritage available on line. Library of Congress [10] believes relying on fair use may be a risky, inappropriate and costly solution, particularly if lawsuits ensue. The Copyright Office "does not believe that reliance on judicial trends, which may turn at any point, is a sufficient basis to forgo a permanent legislative solution" [11, p.43]. On the other hand, some authors defend this model. The Library Copyright Alliance [12] maintains that libraries do not require any legislative reform to be able to make use of orphan works on the basis that fair use has ceased to be uncertain in practice, court orders are less likely and massive digitisation is more commonplace.

Cultural institutions have developed unofficial codes of best practices ${ }^{4}$ that constitute useful documents so that institutions can apply fair use correctly. However, no comprehensive search procedures or lists of information sources have yet been developed, nor is there any official evidence that diligent search processes must be recorded on a database. It is possible to infer that those entities opting to make their collections accessible on-line probably have a record of the diligent search carried out.

There are several well-known cases of digitisation of collections in the Library of Congress. These would include the "The Hannah Arendt Papers" or "Prosperity and Thrift: The Coolidge Era and the Consumer Economy" and, in view of their historical and cultural value, they have been placed on-line partly by means of fair use formulas ${ }^{5}$, including usage clauses in the corresponding sections of "Copyright and Other Restrictions” [10].

\subsection{Extended Collective Licensing}

ECL consists in extending a licence from a representative management entity to rights holders who are not members of that management entity. "The government authorizes a collective organization to deal licences for a class of works or a class of uses" [13, p.36]. Within ECL regimes, searches may be carried out by the Collective Management Organizations (CMOs) (not the end user), and the search can be deferred until a later

\footnotetext{
${ }^{3}$ The two largest digitisation projects, Google Books and HathiTrust Digital Library, have been supported by American judges in favour of fair use.

${ }^{4}$ Code of Best Practices in Fair Use for Academic and Research Libraries; Statement of Best Practices in Fair Use of Orphan Works for Libraries \& Archives; Orphan Works: Statement of Best Practices

${ }^{5}$ https://memory.loc.gov/ammem/arendthtml/res.html
} 
moment (after the orphan work has been used), when the CMO must distribute the royalties to the rights holders it represents [14].

In the United States, the Copyright Office proposes the implementation of this regulatory framework to solve the problem of orphan works, in such a way that licences can be used to authorize projects on the terms established by the parties under governmental supervision. In this Copyright Office proposal, no provisions are made regarding diligent search procedures or lists of information resources for the identification and location of copyright holders.

\subsection{Non-exclusive Licensing}

This model enables users to use certain kinds of orphan works following a case by case analysis. If applicants can prove that they made a reasonable effort to locate the rights holders, but these could not be located, then the competent authority will approve the application and issue non-exclusive conditional licence [11].

Canada opted for this model even though it is not in favour of large-scale digitisation. The Orphan Works Report identified some difficulties in the Canadian system and claims that several studies have highlighted that it is rarely used [15].

According to the on-line guide published by the Copyright Board of Canada, one of the requirements for the granting of licences is to demonstrate the efforts made to locate the rights holders and the results achieved. Nonetheless, only general recommendations ${ }^{6}$ are given, so it is not possible to view exhaustive procedures and information sources for conducting diligent searches. For example, no mention is made of the Copyrights database, which enables the on-line search for copyright information recorded or eliminated since October 1991.

The Copyright Board of Canada keeps an online register of licences issued ${ }^{7}$. To date, 296 licences have been awarded, of which 36 belong to 16 cultural institutions. Nonetheless, the licences respond to requests to use few documents. The National Film Board of Canada is the entity with the most licences granted, 16, almost half the total.

We can infer that institutions with repeated requests for licences have records and case files for the search process to identify rights owners that are more complete than the recommendations mentioned, which are not accessible.

\subsection{Fair Dealing Exceptions}

Under this scheme, a series of exceptions are set out in statute as not constituting an infringement of the copyright in the work.

Australia contemplates in Division 3 of the Copyright Act [16] a series of exceptions covering fair dealing for several purposes. With respect to cultural institutions, the Australian law includes provision $200 \mathrm{AB}^{8}$, which determines certain uses by libraries and archives that would not be considered as an infringement, but no specific exception is set out for the use of orphan works.

In view of this situation of "legislative vacuum", the Australian Law Reform Commission $^{9}$ [17] recommends the introduction of legislation on fair use exception and the limitation of legal remedies where a diligent search has been conducted; this would include cultural institutions and the use of orphan works.

Nonetheless, on this occasion we have also been unable to find any official documents detailing the diligent search process. Some general recommendations can be found in the

\footnotetext{
${ }^{6}$ http://www.cb-cda.gc.ca/unlocatable-introuvables/brochure2-e.html

${ }^{7}$ http://www.cb-cda.gc.ca/unlocatable-introuvables/licences-e.html

8 "Use of works and other subject matter for certain purposes"

${ }^{9}$ Federal agency in charge of investigating, conducting consultancy activities and drawing up recommendations for the government
} 
guidelines drawn up by the National and State Libraries of Australasia [18]. Nor is there any mention in the law of the existence of a register or database listing the works considered, a priori, to be orphans.

Under provision 200AB of the 1968 Copyright Act, Australian libraries provide on-line access to different collections of orphan works after declaring that a diligent search has been carried out. This would be the case of the National Gallery of Victoria which explains, in its section on "Copyrights and Reproductions" ${ }^{10}$, that the works whose rights holders have been impossible to locate are published on-line with the argument that this is the also the best way to discover the owners of the rights. In the same line, the State Library of South Australia publishes certain items under the premise of good faith ${ }^{11}$.

\section{In Search of Solutions: Summary and Projection}

The search for solutions to overcome the obstacles imposed by orphan works for the digitisation and digital dissemination of collections continues to be a topic of interest and a pending issue in the international arena.

Within the European Union, the option adopted has been to implement a model driven by the interest to make all necessary efforts prior to having the works declared as orphans so that they can be used by all member states. In view of the results, the European model is gradually gaining ground thanks to the advances made by member states relating to detailed diligent search procedures and databases enabling this process to be documented.

In the United States, the lack of a consensus on orphan works legislation has meant other alternatives have to be explored. Although the Fair Use model causes uncertainty, the LCA [19] argues that other models also fail to provide an effective solution for mass digitisation.

In this quest for solutions, we can see that Australia tends towards a model based on Fair Use, like that currently in place among North-American cultural institutions.

The Non-Exclusive Licensing model used by Canada also seems not to be effective in view of the results, especially for large digitisation projects.

As for the initiatives to resolve the problems associated with protected works, in Europe, the declaration of such works as orphans and their registration on the European database enable the material to be digitalised by cultural institutions. In the United States and Australia have opted to include notices of their procedure in the Copyright clauses, as well as serving as a means for legitimate holders to claim their rights.

In short, we have seen that the global situation is uncertain and that none of the formulas studied enables full and effective digital dissemination of the world's cultural heritage. It is evident that the path for finding solutions and responses to the challenges posed undoubtedly passes through the need to achieve advances in the formulation of diligent search procedures and mechanisms enabling the results and best practices to be shared among institutions.

\footnotetext{
${ }^{10}$ https://www.ngv.vic.gov.au/about/reports-and-documents/copyright-and-reproductions/

${ }^{11} \mathrm{http}: / /$ www.samemory.sa.gov.au/site/page.cfm?u=70\&c=540
} 


\section{References}

1. Lucas-Schloetter, A.: Digital Libraries and Copyright Issues: Digitization of Contents and the Economics Rights of the Autor. In: Iglezakis, I., Synodinou, T.E, Kapidakis, S. (eds.) E-publishing and Digital Libraries, pp. 159-179, IGI Global, New York (2011).

2. Koskinen-Olsson, T., Lowe, N.: Educational Material on Collective Management of Copyright and Related Rights, WIPO (2012), http://www.wipo.int/edocs/pubdocs/en/wipo_pub_emat_2014_4.pdf, last accessed 2017/09/17.

3. Arquero-Avilés, R., Marco-Cuenca, G.: Análisis del estado de la declaración de obras huérfanas en Europa. Revista General de Información y Documentación 26(2), 365-385 (2016). https://doi.org/10.5209/RGID.54707

4. European Parliament: Directive 2012/28/EU of the European Parliament and of the Council of 25 October 2012 on Certain Permitted Uses of Orphan Works (2012), https://goo.gl/WSPsdQ, last accessed 2017/09/17.

5. Arquero-Avilés, R. (coord.).: Estudio comparativo y análisis de la situación actual de las obras huérfanas en Europa, Observatorio de Obras Huérfanas y Búsqueda Diligente, Madrid (2017). ISBN 978-84-697-4066-8, https://www.researchgate.net/publication/318085151, last accessed 2017/09/17.

6. Bertoni, A., Guerrieri, F., Lillà, M.: Requirements for Diligent Search in 20 European Countries (2017), http://diligentsearch.eu/wp-content/uploads/2017/06/REPORT-2.pdf, last accessed 2017/09/17.

7. Favalle, M., Schoroff, S., Bertoni, A.: Requirements for Diligent Search in the United Kingdom, the Netherlands and Italy (2016), https://goo.gl/zBQiKS, last accessed 2017/09/17.

8. EUIPO. Annual Report: European Union Intellectual Property (2016), https://goo.gl/eKmNmU, last accessed 2017/09/17.

9. Stim, R.: Getting Permission: Using \& Licensing Copyright-Protected Materials Online \& Off. NOLO (2016)

10. Library of Congress: Comments of the Library of Congress in Response to the Copyright Office Notice of Inquiry (2013), https://goo.gl/voAYMa, last accessed 2017/09/17.

11. United States Copyright Office: Orphan Works and Mass Digitization (2015), https://www.copyright.gov/orphan/reports/orphan-works2015.pdf, last accessed 2017/09/17.

12. Library Copyright Alliance: Comments of the Library Copyright Alliance in Response to the Copyright Office’s Notice of Inquiry (2013), https://goo.gl/419yvA, last accessed 2017/09/17.

13. United States Copyright Office: Legal Issues in Mass Digitization: a Preliminary Analysis and Discussion Document (2011), https://goo.gl/GC5a3y, last accessed 2017/09/17.

14. Hansen, D.R., Hinze, G., Urban, J.: Orphan Works and the Search for Rightsholders: Who Participates in a 'Diligent Search' Under Present and Proposed Regimes (Berkeley Digital Library Copyright Project, White Paper No. 4) (2013), http://ssrn.com/abstract=2208163

15. United States Copyright Office: Report on Orphan Works (2006), https://www.copyright.gov/orphan/orphan-report.pdf, last accessed 2017/09/17.

16. Copyright Act 1968 (consolidated as of June 27, 2015), http://wipo.int/wipolex/en/details.jsp?id=15724, last accessed 2017/09/17.

17. Australian Law Reform Commission: Copyright and the Digital Economy, Final Report (ALRC Report 122) (2014), https://www.alrc.gov.au/publications/13-orphan-works, last accessed 2017/09/17. 
18. National and State Libraries Australasia: Procedural Guidelines for Reasonable Search for Orphan Works (2010), https://goo.gl/hexYtw, last accessed 2017/09/17.

19. Library Copyright Alliance: Additional Comments of the Library Copyright Alliance in Response to the Copyright Office's Notice of Inquiry Concerning Orphan Works and Mass Digitization (2014), https://goo.gl/TToucd, last accessed 2017/09/17. 